\title{
Family Variables as Predictors of Self-Concept and Academic Achievement of Secondary School Students in Benue State, Nigeria
}

\author{
Eucharia Nchedo Aye ${ }^{1}$, Richard Agbangwu ${ }^{1}$, Theresa Olunwa Oforka ${ }^{1}$, Julia Amobi Onumonu ${ }^{1}$, \\ Ngozi Hope Chinweuba ${ }^{1}$, Nkiru Christiana Ohia ${ }^{1}$, Celestine Okwudili Eze ${ }^{1}$, \\ Ngozi Eucharia Eze ${ }^{1} \&$ Immaculata Nwakaego Akaneme ${ }^{1}$ \\ ${ }^{1}$ Department of Educational Foundations, University of Nigeria, Nsukka, Nigeria \\ Correspondence: Immaculata Nwakaego Akaneme, Department of Educational Foundations, University of \\ Nigeria, Nsukka, P.M.B. 410001, Enugu State, Nigeria. E-mail: immaculata.akaneme@unn.edu.ng
}

Received: May 12, 2019 Accepted: June 15, 2019 Online Published: July 1, 2019

doi:10.5539/gjhs.v11n8p86 URL: https://doi.org/10.5539/gjhs.v11n8p86

\begin{abstract}
Objective: The study investigated family variables as predictors of self-concept and academic achievement of secondary school students in Benue state, Nigeria.

Methods: The study adopted a correlational research design. The sample of the study consisted of seven hundred and twenty (720) SS II students. The study research questions were analyzed using the Pearson product moment correlation coefficient, while the hypotheses were tested using regression analysis at 0.05 probability level.

Results: The findings revealed a strong positive relationship among family structure, self-concept and academic achievement of secondary schools students. It also revealed that family leadership style like Authoritative, Authoritarian, Permissive and Neglectful family leadership style had a strong relationship on secondary school students, self-concept and academic achievement. Again, it was discovered that family size had a strong relationship on secondary school students' self-concept and academic achievement in Benue state, Nigeria.

Conclusion: It is concluded that there exists a strong relationship between family structure and self-concept of secondary school students; family structure predicts students' academic achievements; family size has a low positive relationship with self-concept of secondary school students; low relationship with student's academic achievement; there is a positive relationship between family leadership styles and self-concept of secondary school students.
\end{abstract}

Keywords: family, self-concept, academic achievement, secondary school, students

\section{Introduction}

In this era of globalization and technological advancement, education is considered as the first step for every human activity in any society. Family is a fundamental unit in the society and the first pot of call for every child where educational and moral training of children take place. In support of the above statement, Idah (2012) described the family as the society's primary social group, the foundation of which individuals have their beginning and through which they experience the major portion of life. Akubue and Okolo (2008) conceptualized family as a social group characterized by common household, economic co-operation among members, reproduction of new members of the society and the socialization of the young ones. The researchers view the family as the first platform of a social unit on which the society anchors her future. It is an institution that has the capacity to make or mar children's self-concept and academic achievement. This is because the family socializes its members to internalize the values, norms, beliefs, morals and ethics and cultural heritage of the society before going to formal school. Ugwanyi (2011) noted that it is within the family that most children first learn how to behave in socially acceptable ways, to develop close emotional ties and to internalize the values and norms of the society. The author believes that experiences within the family help to shape the personality of individuals, which in turn helps to produce a society of individuals who share in the pattern of larger culture.

In line with the above claim, Akubue and Okolo (2008) agree that during the formative years of the child, the family exerts tremendous and far-reaching influences on the child's habit and attitude formation. Succintly put, the child's physical growth, cognitive, moral, emotional and spiritual development is dependent on his/her family support, training and care. In other words, the child obtains his/her status and class position from the family. The 
child builds up self-concept based on the status of the family in society. The child, therefore, learns rudimentary skills which include how to talk, walk, eat, and acceptable behavioural patterns such as greetings, respect for elders, obedience and honesty from the family.

The elderly members of the family socialize the younger ones to learn the moral code of the society they belong to by performing certain activities in the home. For example, the child learns the habits of greeting, way of dressing, eating, keeping the home clean, feeding animals, running errands, praying, caring for the younger children, farming, carving, fishing, painting, roofing and other related activities. Osunloye (2008) opined that family affects the individual since the parents are the first socializing agent in an individual's life. This is because the family factors in the context of a child, affect his/her reaction to life situations and his/her level of achievement.

Family factors refer to all the conditions and the circumstances in the family which influence the child physically, intellectually, and emotionally. Omeh (2010) sees family factors as key variables playing significant roles in the family setting that tend to encourage or discourage a child's self-concept and academic pursuit. It makes or mars the morale of a child in his/her academic pursuit. Family factors are those influences in the family that can transform a child either positively or negatively and portray the family as good or bad background. These factors include good morals, obedience, societal ethics, values, and beliefs. These are some of the factors that can predict a child's self-concept and academic achievement. The researchers see family factors as those influences in the family that can predict both child's self-concept and academic achievement. Such factors include family size, family structure or family types, and family child rearing practices which contribute to a child's personality worth that can make him/her compete favourably with his/her counterparts in the school environment. Family size in this context refers to the total number of children in the child's family which can be small or about two to six or a large family of seven and above. It determines the parenting of the children.

Parenting styles which are also interchangeably called child rearing practices are approaches adopted by families to train their children. Family parenting is a factor that contributes to the development of the child. Saleh (2009) described single parenting families as families in which either the father or mother is involved in the training of the children. The author noted that this situation could arise as a result of death, divorce or unwanted pregnancy from single ladies before marriage. On the other hand, the author stated that both parent families are those in which both father and mother are involved in the training of the children. The third parent type which the author mentioned is the stepparent families where the parent of the children might have died and relatives of the deceased take over the training of the children.In this case, either the nuclear or extended family members can parent the children.

Parental involvement is a necessary impetus for child upbringing. Jeynes (2008) examined the importance of parental involvement in a child's training in relation to a child's self-concept and academic achievement. The author found out that parental involvement had a positive impact on a child's academic achievement across diverse populations of children. The author also revealed that children who received proper parenting excel both in developing positive self-concept and achieving high academically. Baumrid (1966) identified three parenting styles most families adopt. These include authoritarian, authoritative and permissive styles.

The author opined that the authoritarian parenting style suggested that children were expected to be submissive to their parent's demands, while parents were expected to be strict, directive, and emotionally detached. Permissive parenting style like the name implied connotes less parental restrictions or limits on the child. The implication of this was that children were expected to regulate their own activities.

Authoritative parenting style is similar to authoritarian parenting except that it entails clear and firm direction to children. The conceptualization of parenting styles as a child rearing method to categorize and measure the worth and form of relations between parents and children began with the research of Baumrid who identified three parenting styles after her study however, identified that the difference between the two similar parenting styles lies in moderating discipline with warmth, reason, and flexibility as ensued by authoritative parenting.

In the context or the study, family factors such as family size, structure, and parenting styles predict self-concept and academic achievement of secondary school students in Agatu Local Government Area of Benue state.

Conversely, when a child is trained or parented by the extended family such as stepfather, mother, uncle, niece or any other extended relation, the predictor of self-concept and academic achievements are dependent on family factors such as family size, the structure and family parenting styles. In support of the above sentence, Mahmoud and Usama (2014) asserted that family functioning was a contributory factor of self-concept for both children with and without learning disabilities. Momolafe and Olorunfemi (2011) also opined that family type has a positive relationship with the academic achievement of secondary school students. Clark (2008) described the extended family as a common African culture where groups of blood-related people live together and share certain things in 
common especially in the parenting of children. Idah (2012) noted that extended family relationship is part of the culture among Benue State indigenes and remarked that large family size and complex family structure in addition to different parenting practices have both positive and negative effects on children's self-concept and academic performance. The author noted that in terms of farm work and other cultural activities that require a sizable number of people that extended family relationship is at an advantage, but at a disadvantage when it comes to a matter of proper parenting both for self-concept and academic performance. Joel (2011) remarked that the more the family is extended the less proper parenting of the children and the low self-concept and academic achievement. Slake (2009) reported that the negative effect of family size on self-concept and educational attainment persists after the socio-economic characteristics of the family is statically controlled. Yagi and Kaur (2001) further asserted that family size either large or small predict self-concept of secondary school students either positively or negatively. Kamaui (2011) observed that family size can predict students' academic achievement of secondary school either positive or negatively. Hoffer (2007) remarked that parents who have many children invest less money, time, emotional and psychic energy, and attention on each child. The author revealed that from the previous studies on family influences on children's self-concept and academic achievement, those children who live with single-parents or step-parents receive less parental encouragement and attention with respect to self-concept and academic achievement than their counterparts who live with both biological parents. The researchers also feel that this revelation from the author indicates that children from non- intact families report lower educational expectations on the part of their parents, less monitoring of school work and less over supervision of social activities than children from intact families.

Self-concept and academic achievement are important yardsticks to measure success in students. In recent time, it has been generally observed that students perform poorly academically. This poor performance in examinations at all levels has attracted criticisms from all quarters. Onu (2012) noted that some accusing fingers pointed at the family upbringing of children, while other accusing fingers point at teachers and government policies and programme.

Closely related to family parenting style is the family structure which plays a crucial role in strengthening or devastating student's self-concept and academic performance. There are different types of family structures, the structures are based on whether both parents are involved in children's training or whether only one of the parents is involved in the training of the children. Family can be classified into nuclear family and extended family. The researchers feel that when parents model the child towards good attitude, such a child stands the chances of being obedient in the classroom, participate in classroom activities and understands the value of education. The researchers see family structure as the embodiment of family types through which a child is nurtured which include nuclear and extended families.

The researchers intend to dwell much on nuclear and extended families in the study. Clark (2008) described the nuclear family as that which consists of husband, wife and the children. Ogbonna (2014) sees the nuclear family as the family that is made up of husband, wife, children and other house-help occupying the same roof. The nuclear family has been acknowledged as the smallest unit of the family. Tutel (2004) defined nuclear family as an institution which comprises father, mother and children under a common roof. The researchers opined that nuclear family is a composition of one man, his wife or wives and children.

The extended family, on the other hand, is a family system consisting of the husband, wife, children, grandparents, uncles, aunts and cousins from both sides (Anyanwu, 2012). In corroboration, Ugwanyi (2011) posit that extended family is the family type that involves father, mother, children, grandparents, uncles, aunties and others. The researchers also view the extended family as the family which consists of two or more nuclear families.

Self-concept has been part of human development and as such, starts from the family. Onu (2012) describes self-concept as the way and manner an individual value him/herself through attitude, aptitude, and interest which guide his future development. The researchers view self-concept as the personal worth of an individual that controls his/her emotion, attitude and perceptions. These beliefs about oneself act as a guide to to evaluate an individual either positively or negatively. It is determined by family factors such as family size, parenting styles, and family structure of both nuclear and extended families which are also the determinant of self-concept and academic achievement.

The attainment of academic achievement of children is dependent on their parenting styles for instance, if parent should rear their children, limit the number of children they can maintain, that is, the size of the family to a small unit of one to six, it is most likely that they can pay attention to their children on an individual basis and provide necessary educational materials, interact with them, assist them in their assignments and develop their self-concept. In this case, children brought up in this manner are most likely to excel in the classroom activities and even beyond. 
On the other hand, if a parent has about ten children in the family, their academic achievement can be marred because the parenting of ten children cannot be as effective as a family parenting two children as it will be difficult if not impossible for a parent to pay adequate attention to their children on individual basis and eat together, assist them in their assignment and develop their self-concept. In this way, it is most likely that their academic performance may be low except for any one of them who is naturally a genius. In the context of this study, secondary school students in Agatu Local Government Area of Benue State are expected to have high academic achievement if these family factors are maintained by various families.

It may be posited that the poor performance of students in external examination like West African School Certificate Examination (WAEC) in 2011 to 2013 and National Examination Council (NECO) the same period might be due to poor parenting, large family size and precarious family structure. The researchers limited the study to family factors such as family size, structure and parenting styles. The main thrust of this study is to investigate how family factors can predict self-concept and academic achievement of secondary school students in Agatu Local Government Area of Benue State.

\section{Research Method}

The study used a correlational research design. The study was conducted in secondary schools in Agatu Local Government Area of Benue State. Agatu Local Government Area of Benue State is predominantly inhabited by farmers, petty traders and local craftsmen and women. It is located in the lower Benue River basin. The location of the local government with rich fertile soil provided an enabling environment for commercial crop production and fish farming. Agatu is made up of semi-urban and rural communities. In farming season $70 \%$ of the rural schools close down for farm work. There are thirty public secondary schools in Agatu Local Government Area of Benue State. The choice of the local government is borne out of the fact that Agatu Local Government is made up of families with multi-cultural background adopting different family structures and family parental styles that may predict or influence their children's' self-concept and academic achievement.

The population of the study comprised all the SS II students in the thirty (30) public secondary schools in Agatu Education zone. The population of the study was two thousand, nine hundred and twenty-three $(2,923) \mathrm{SS}$ II students of secondary schools in the Education Zone (Source: Benue state education zone, Agatu).

The sample of the study was 720 students. Multi-stage sampling technique was adopted, two out of three local government areas namely: Agatu North and South were sampled; twenty secondary schools out of thirty were sampled; that is, ten each from the sampled local government areas were used. Seven hundred and twenty (720) male and female students of SSII that is, 720 (360 males and 360 females) were sampled from each school for the study. For example, a multistage sampling technique was used, in the first instance, 2 out of the 3 local government areas were sampled. From these 2 sampled areas, 20 secondary schools were randomly selected that is, 10 schools from each local government area. A sample of 720 SSII students made up of 360 males and 360 females totalling 720 students were randomly selected from each and the ten schools.

The instruments that were used for data collection are the Family Factor and Self Concept Questionnaire (FFSCQ), the Student's Academic Achievement Result (SAAR). The family factor and self-concept questionnaire were divided into two sections. The students' academic achievement result (SAAR) which is concerned with students' academic achievement and students' annual result for four years in five compulsory subjects was used.

The instrument was face validated by three experts one in Measurement and Evaluation, two in the Sociology of Education and Special Education in the Faculty of Education.

The questionnaire was trial tested using five public secondary schools in Agatu East Local Government that is not covered in the process of sampling. The data collected through the trial testing of the instrument was used to determine the internal consistency estimate in each cluster of the instrument and the overall estimate of the entire instrument. The internal consistency reliability estimate obtained using Cronbach Alpha method are 0.82, 0.76, $0.80,0.75$ and 0.81 for cluster $\mathrm{A}, \mathrm{B}, \mathrm{C}$ and $\mathrm{D}$ respectively. The internal consistency reliability estimate for overall items is 91 implying that the consistency reliability is high enough to consider the instrument reliable.

The questionnaire was prepared in clusters and sections to measure the purpose of the study. After effecting the suggestions of the experts who validated the instrument, copies of the questionnaire were made in numbers according to the sampled size of the population of the study. To ensure maximum returns of the questionnaire the instrument was administered to the students of SSII with the help of their teachers. The research questions were answered using Pearson's product correlation coefficient while the hypotheses were tested using regression statistic at 0.05 probability level. 


\section{Results}

Research Question One: What is the relationship between family structure and self-concept of secondary school students?

Table 1. Regression analysis of the relationship between family structure and the self-concept of secondary school students

\begin{tabular}{lllll}
\hline Model & $\mathrm{R}$ & $\mathrm{R}$ Square & Adjusted R Square & Std. Error of the Estimate \\
\hline 1 & $.338^{\mathrm{a}}$ & .114 & .021 & 6.48948 \\
\hline
\end{tabular}

a. Predictors: (Constant), Extended Family Structure, Nuclear Family Structure

Table 1 showed the regression analysis of the relationship between family structure and the self-concept of secondary school students. It revealed that the correlation between family structure and self-concept of secondary school students was 0.338 with a coefficient of determination of 0.114 . This indicated that 11.4 per cent variation in students' self-concept can be attributed to family structure.

Research Question Two: What is the relationship between family structure and academic achievement of secondary school students?

Table 2.Regression analysis of the relationship between family structure and the academic achievement of secondary school students

\begin{tabular}{lllll}
\hline Model & $\mathrm{R}$ & R Square & Adjusted R Square & Std. Error of the Estimate \\
\hline 1 & $.451^{\mathrm{a}}$ & .204 & .120 & 13.52318 \\
\hline
\end{tabular}

a. Predictors: (Constant), Extended Family Structure, Nuclear Family Structure.

Analysis of data in Table 2 revealed the regression analysis of the relationship between family structure and academic achievement of secondary school students. It showed that the correlation between family structure and academic achievement of secondary school students was 0.451 with a coefficient of determination of 0.204 . This implied that 20.4 per cent variation in students' academic achievement can be attributed to family structure.

Research Question Three: What is the relationship between family size and self-concept of secondary school students?

Table 3. Regression analysis of the relationship between family size and the self-concept of secondary school students

\begin{tabular}{lllll}
\hline Model & $\mathrm{R}$ & R Square & Adjusted R Square & Std. Error of the Estimate \\
\hline 1 & $.065^{\mathrm{a}}$ & .004 & -.019 & 7.43832 \\
\hline
\end{tabular}

a. Predictors: (Constant), Family Size.

Table 5 showed the regression analysis of the relationship between family size and self-concept of secondary school students. It indicated that the correlation between family size and self-concept of secondary school students was 0.065 with a coefficient of determination of 0.004 . This implied that 0.4 per cent variation in students' self-concept can be attributed to family size.

Research Question Four: What is the relationship between family size and academic achievement of secondary school students? 
Table 4. Regression analysis of the relationship between family size and academic achievement of secondary school students

\begin{tabular}{lllll}
\hline Model & $\mathrm{R}$ & R Square & Adjusted R Square & Std. Error of the Estimate \\
\hline 1 & $.050^{\mathrm{a}}$ & .002 & .023 & 15.40905 \\
\hline
\end{tabular}

a. Predictors: (Constant), Family Size.

Analysis of data in Table 4 showed the regression analysis of the relationship between family size and academic achievement of secondary school students. It revealed that the correlation between family size and academic achievement of secondary school students was 0.020 with a coefficient of determination of 0.05 . This implied that 0.2 per cent variation in students' achievement can be attributed to family size.

Research Question Five: What is the relationship between family leadership styles and self-concept of secondary school students?

Table 5. Regression analysis of the relationship between family leadership styles and the self-concept of secondary school students

\begin{tabular}{lllll}
\hline Model & $\mathrm{R}$ & R Square & Adjusted R Square & Std. Error of the Estimate \\
\hline 1 & $.516^{\mathrm{a}}$ & .266 & .144 & 7.52849
\end{tabular}

a. Predictors: (Constant), Neglectful Permissive Family leadership style, Authoritarian Family parental style, Authoritative Family parental style.

Table 5 revealed that the correlation between family styles leadership self-concept of secondary school students was 0.516 with a coefficient of determination of 0.266 . This implied that 26.6 per cent variation in students' self-concept can be attributed to family leadership styles.

Research Question Six: What is the relationship between family leadership styles and academic achievement of secondary school students?

Table 6. Regression analysis of the relationship between family leadership styles and academic achievement of secondary school students

\begin{tabular}{lllll}
\hline Model & $\mathrm{R}$ & R Square & Adjusted R Square & Std. Error of the Estimate \\
\hline 1 & $.539^{\mathrm{a}}$ & .272 & .127 & 15.03244 \\
\hline
\end{tabular}

a. Predictors: (Constant), Neglectful Leadership Style, Authoritarian Family parental style, Authoritative Family parental style.

Table 6 showed the regression analysis of the relationship between family leadership styles and academic achievement of secondary school students. It revealed that the correlation between family parental styles and academic achievement of secondary school students was 0.539 with a coefficient of determination of .272 . This implied that 27.2 per cent variation in students' academic achievement can be attributed to family leadership styles.

Hypothesis One: There is a significant relationship between family structure and self-concept of secondary school students.

Table 7. Analysis of variance of the relationship between family structure and self-concept of secondary school students

\begin{tabular}{llllll}
\hline Model & Sum of Squares & Df & Mean Square & F & Sig. \\
\hline Regression & 102.938 & 2 & 51.469 & 11.222 & $.017^{\mathrm{b}}$ \\
1 Residual & 800.153 & 19 & 42.113 & & \\
Total & 903.091 & 21 & & & \\
\hline
\end{tabular}

a. Dependent Variable: Self Concept.

b. Predictors: (Constant), Extended Family Structure, Nuclear Family Structure. 
Table 7 showed that the probability associated with the calculated value of $\mathrm{F}$ (11.222) for the relationship between family structure and self-concept, was 0.017 . This implied that there is no significant relationship between family structure and self-concept of secondary school students.

Hypothesis Two: There is a significant relationship between family structure and academic achievement of secondary school students.

Table 8. Analysis of variance of the relationship between family structure and academic achievement of secondary school students

\begin{tabular}{lllllll}
\hline \multicolumn{1}{l}{ Model } & Sum of Squares & Df & Mean Square & F & Sig. \\
\hline \multirow{3}{*}{1} & Regression & 888.849 & 2 & 444.424 & 22.430 & $.001^{\mathrm{b}}$ \\
& Residual & 3474.651 & 19 & 182.876 & & \\
& Total & 4363.500 & 21 & & & \\
\hline
\end{tabular}

a. Dependent Variable: Achievement.

b. Predictors: (Constant), Extended Family Structure, Nuclear Family Structure.

Table 8 showed that the probability associated with the calculated value of $\mathrm{F}(22.430)$ for the relationship between family structure and academic achievement of secondary school students was 0.001 . This implied that there is a significant relationship between family structure and academic achievement of secondary school students.

Hypothesis Three: There is a significant relationship between family size and self-concept of secondary school students.

Table 9. Analysis of variance of the relationship between family size and self-concept of secondary school students

\begin{tabular}{cccccc}
\hline Model & Sum of Squares & Df & Mean Square & F & Sig. \\
\hline Regression & 10.116 & 1 & 10.116 & .183 & $.671^{\text {b }}$ \\
1 Residual & 2379.129 & 43 & 55.329 & & \\
& Total & 2389.244 & 44 & & \\
\hline
\end{tabular}

a. Dependent Variable: Self Concept.

b. Predictors: (Constant), Family Size.

Table 9 showed that the probability associated with the calculated value of F (.183) for the relationship between family size and students' self-concept, is 0.671 . Thus, there is no significant relationship between family size and self-concept of secondary school students.

Hypothesis Four: There is a significant relationship between family size and academic achievement of secondary school students.

Table 10. Analysis of variance of the relationship between family size and academic achievement of secondary school students

\begin{tabular}{|c|c|c|c|c|c|}
\hline Model & Sum of Squares & Df & Mean Square & $\mathbf{F}$ & Sig. \\
\hline Regression & 4.124 & 1 & 4.124 & .017 & $.896^{\mathrm{b}}$ \\
\hline 1Residual & 10209.876 & 43 & 237.439 & & \\
\hline Total & 10214.000 & 44 & & & \\
\hline
\end{tabular}

a. Dependent Variable: Achievement;

b. Predictors: (Constant), Family Size.

Table 10 showed that the calculated value of F (9.539) for the relationship between family leadership styles and 
students' self-concept has an associated probability value of 0.896 . This implied that there is no significant relationship between family leadership styles and self-concept of secondary school students.

Hypothesis Five: There is a significant relationship between family leadership styles and self-concept of secondary school students.

Table 11. Analysis of variance of the relationship between family leadership styles and self-concept of secondary school students

\begin{tabular}{lllllll}
\hline Model & Sum of Squares & Df & Mean Square & F & Sig. \\
\hline \multirow{3}{*}{1} & Regression & 122.116 & 4 & 30.529 & 9.539 & $.008^{\mathrm{b}}$ \\
\cline { 3 - 5 } & Residual & 2267.129 & 40 & 56.678 & & \\
\cline { 2 - 5 } & Total & 2389.244 & 44 & & & \\
\hline
\end{tabular}

a. Dependent Variable: Self Concept.

b. Predictors: (Constant), Neglectful Permissive Family leadership style, Authoritarian Family leadership style, Authoritative Family leadership style.

Table 11 showed that the probability associated with the calculated value of $F(.017)$ for the relationship between family size and students' self-concept was 0.008 . Thus, there is significant relationship between family size and academic achievement of secondary school students.

Hypothesis Six: There is no significant relationship between family leadership style and academic achievement of secondary school students.

Table 12.Analysis of variance of the relationship between family leadership styles and academic achievement of secondary school students

\begin{tabular}{lllllll}
\hline Model & & Sum of Squares & Df & Mean Square & F & Sig. \\
\hline \multirow{2}{*}{1} & Regression & 1175.026 & 4 & 293.757 & 21.300 & $.006^{\mathrm{b}}$ \\
& Residual & 9038.974 & 40 & 225.974 & & \\
& Total & 10214.000 & 44 & & & \\
\hline
\end{tabular}

a. Dependent Variable: Achievement.

b. Predictors: (Constant), Neglectful Permissive Family leadership style, Authoritarian Family parental style, Authoritative Family parental style.

Table 12 showed that the calculated value of $\mathrm{F}$ (21.300) for the relationship between family leadership styles and students' achievement has an associated probability value of .006. This implied that there is significant relationship between family leadership styles and academic achievement of secondary school students.

\section{Discussion}

\subsection{The Relationship between Family Structure and Self-Concept of Secondary School Students}

The finding of the study revealed that family structure has a low positive relationship with students' self-concept. This implies that there is low positive relationship between family structure which includes nuclear and extended families and self-concept of students according to the respondents. This finding is in agreement with the findings of Mahmoud and Usama (2014) who noted that family functioning was a contributory factor of self-concept for both children with and without learning disabilities. The result of the hypothesis one showed no significant positive relationship between family structure and self-concept of secondary school students. This led to the acceptance of hypothesis one which stated that there is no significant relationship between family structure and self-concept of students.

\subsection{The Relationship between Family Structure and Academic Achievement of Secondary School Students}

The finding of the present study showed that there is a strong positive relationship between family structure and academic achievement of students in secondary school. This result is in agreement with the findings of Momolafe 
and Olorunfemi (2011), who opined that family type has a positive relationship with the academic achievement of secondary school students. The result of hypothesis two revealed a significant relationship between family structure and academic achievement of secondary school students.

\subsection{The Relationship between Family Size and Self-Concept of Secondary School Students}

The finding indicated a very low positive relationship between family size and self-concept of the students in secondary school. The finding agreed with Yagi and Kaur (2001) who asserted that family size either large or small predict self-concept of secondary school students either positively or negatively. The result of hypothesis showed a low significant relationship between family size and self-concept of secondary school students. This led to the acceptance of hypothesis three.

\subsection{The Relationship between Family Size and Academic Achievement of Secondary School Students}

The result of the finding indicated a very low positive relationship between family size and students' academic achievement in secondary school. This finding is in agreement with Kamaui (2011) who observed that family size can predict students' academic achievement of secondary school either positive or negatively. The result of hypothesis four showed a significant relationship between family size and academic achievement of secondary school students.

\subsection{The Relationship between Family Leadership Styles and Self-Concept of Secondary School Students}

The result of the finding established a positive relationship between family leadership styles and self-concept of secondary school students. The finding is in agreement with Idah (2012) who noted that extended family relationship is part of the culture among Benue State indigenes and remarked that large family size and complex family structure in addition to different leadership or parenting practices have both positive and negative effects on children's self-concept and academic performance. The result of hypothesis showed a low significant positive relationship between family leadership style and self-concept of secondary school students. Hence, the null hypothesis five which stated that there is no significant relationship between family leadership styles and self-concept of secondary school students was accepted.

\subsection{The Relationship between Family Leadership Style and Academic Achievement of Secondary School Students}

The finding of the study indicated a low positive relationship between family leadership styles and academic achievement of secondary school students. The finding agreed with Kamaui (2011) who asserted that the family background of students can predict their academic achievement positively or negatively. The result of the hypothesis six showed a significant relationship between family leadership styles and academic achievement of secondary school students which led to the rejection of the null hypothesis which stated that there is no significant relationship between family leadership styles and academic achievement of secondary school students.

\section{Conclusion}

It is concluded that there exists a strong relationship between family structure and self-concept of secondary school students. The analysis also showed that family structure predicts students' academic achievements. The family size indicated a very low positive relationship with self-concept of secondary school students. It also indicates a low relationship with students' academic achievement. The analysis presented the result which showed a low positive relationship between family leadership styles and self-concept of secondary school students.

\section{Competing Interests Statement}

The authors declare that there are no competing or potential conflicts of interest.

\section{References}

Akubue, F. N., \& Okolo, A. N. (2008). Sociology of education. Nsukka, Nigeria: Great A.P. Express Publishers Ltd.

Anyanwu, F. (2012). The causal ordering of academic achievement and self-concept of ability during elementary school: A longitudinal study. Journal of Educational Psychology, 87, 624-637. https://doi.org/10.1037//0022-0663.87.4.624

Baumrid, D. (1966). Prototypical descriptions of 3 parenting styles: Effect of authoritative parental control on child behaviour. Child Development, 37(4), 887-907.

Clark, D. J. (2008). Father presence, family structure, and feelings of closeness to the father among adult African American children. Journal of Black Studies, 38, 529-546. https://doi.org/10.1177/0021934705286101

Hoffer, T. M. (2007). Becoming a brilliant star: an introduction. Paper Presentation at The Forum for Integrated 
Education and Educational Reform, Santa Cruz, CA.

Idah, I. L. (2012). The relationship between school climate, academic self-concept and academic achievement. Dissertation Abstracts international section A Humanities and Social Sciences, 6295-A, 1717.

Jeynes, (2008). Secondary Education: a new look at Nigeria adolescents and young adults. Retrieved November 28, 2015, from www.google.com

Joel, K. (2011). Casual effects of academic self- concept on academic achievement: Structural equation of longitudinal data. Journal of Education Psychology, 89, 41-54. https://doi.org/10.1037/0022-0663.89.1.41

Kamaui .L. (2011). Self perception and performance predictors of academic self-concept: a longitudinal perspective. British Journal of Education Psychology, 67, 263-77. https://doi.org/10.1111/j.2044-8279.1997.tb01243.x

Mahumoud \& Usama. (2014). Family predictors of self-concept and self-esteem in children at risk for learning disabilities. Oman. International Education Studies, 7, 89-92. https://doi.org/10.5539/ies.v7n10p89

Momolafe,\&Olorunfemi, O. (2011).The impact of family type on secondary school student's academic performance in Nigeria, Ondo State.

Ogbonna I. G. (2014). Self -concept as a predator of college freshman academic adjustment. College Student Journal, 36, 234-246.

Omeh, G. (2010). Self-concept, academic performance and behavioral evaluation of the children of alcoholic parents. RevistaBrasileria de Psiquiatria, 27, 233-226. https://doi.org/10.1590/S1516-44462005000300014

Onu I. (2012). In-service training needs of secondary school principals for the implementation of basic education programme in South East Nigeria. Unpublished Doctoral Thesis, University of Nigeria, Nsukka.

Osunuonye, B. M. (2008). Parental alcohol use and adolescent school adjustment in the general population: Results from the HUNT study. BMC Public Health, 11, 1-11.

Salem, P. (2009). The emergence of triage in family court services: The beginning of the end for mandatory mediation? Family Court Review, 47, 371-388.

Slake. (2009). Raising minority academic achievement: A compendium of education programmes and practices. Washington DC: American Youth Policy Forum.

Tutel, F. (2004). Positive parenting, family cohesion, and child social competence among immigrant Latino families. Journal of Family Psychology, 24, 252-260. https://doi.org/10.1037/a0019407

Ugwanyi B. E. (2011). Family structure states and transitions: Associations with children's wellbeing during middle childhood. Journal of Marriage and Family, 71, 575-591. https://doi.org/10.1111/j.1741-3737.2009.00620.x

Yagi, B., \& Kaui, F. (2001). Parental behaviors and adolescent academic performance: A longitudinal analysis. Journal of Research on Adolescence, 6, 113-137.

\section{Copyrights}

Copyright for this article is retained by the author(s), with first publication rights granted to the journal.

This is an open-access article distributed under the terms and conditions of the Creative Commons Attribution license (http://creativecommons.org/licenses/by/4.0/). 